https://doi.org/10.48009/1_iis_2010_473-482

\title{
SOCIAL MANAGEMENT NETWORKS: ANALYSIS OF POSTINGS IN FACEBOOK GROUPS RELATED TO WILDLIFE MANGEMENT AND PROSPECTS FOR DATA COLLECTION
}

\author{
G. Kent Webb, San Jose State University, webb_k@cob.sjsu.edu
}

\begin{abstract}
Rapid acceptance and development of social network applications provide opportunities to gather data at low costs and to allow for coordinated use of this information for management. The phrase "social management networks" is proposed to focus study on social networks used for management objectives. This paper examines frequency of postings on Facebook groups related to wildlife management in order to see how this application is being developed to support these social management networks. Also, a survey of college business students is analyzed to see how social networking applications might be used to support environmental scanning using surveys. The results suggest that many social management networks have only modest or little success, but there are some significant successes. Postings in Facebook groups tend to be linearly related to group size, except when very large groups are also considered. Online surveys significantly increase participation compared to mailed surveys as measured by intended participation rates. Adding Facebook, MySpace, or Twitter support can marginally improve participation rates for an online survey.
\end{abstract}

Keywords: Social Networking, Management Information Systems, Environmental Scanning

\section{INTRODUCTION}

Although the specific phrase "social management network" does not generate any hits using Google scholar to search on all text of articles, social networks organized to achieve management goals are quite common in practice. A search on the word "management" in March, 2010, on Facebook revealed that there were about 128,000 related groups. A quick inspection of the results reveals many Facebook groups organized around management objectives, such as: Republik Clinta Management with 17,499 members which describes itself "as a professional company dedicating its business mainly in managing professional activities of Indonesian musicians"; Traffic Management
Center with 13,928 members involved with traffic management in Jakarta; and, Save Algonquin Park with 43,154 members, a conservation group organizing to help manage the Algonquin Provincial Park in Canada. These management groups range in interest from business to political, environmental to entertainment. The Facebook application provides them with a convenient way to exchange information and to organize or extend their organization.

There has been extensive research on how organizational networks play a role in knowledge creation and transfer. Inkpen and Tsang [1] note that researchers have focused on how through membership in networks the "potential for knowledge acquisition is created." Wasko and Faraj show that people are willing to participate in electronic networks to enhance their professional reputations or are embedded somehow in the network even without the expectation of reciprocity or even of high levels of commitment to the network. [2[

Social network applications occupy three of the top ten trafficked sites on the Internet in March, 2010 (Table 1). Most of the sites in the top ten support some form of interactive communications. Facebook, Myspace, and Twitter are primarily designed for this application.

\begin{tabular}{|l|l|}
\hline \multicolumn{2}{|l|}{ Table 1: Top 10 Internet Sites by Traffic Volume } \\
\hline Rank & Site Name \\
\hline 1 & Google.com \\
\hline 2 & Facebook.com \\
\hline 3 & Youtube.com \\
\hline 4 & Yahoo.com \\
\hline 5 & Bing.com \\
\hline 6 & Wikipedia.org \\
\hline 7 & Blogger.com \\
\hline 8 & MSN.com \\
\hline 9 & Twitter.com \\
\hline 10 & Myspace.com \\
\hline Source: & TrafficEstimate.com, March, 2010 \\
\hline
\end{tabular}

Google offers the newly introduced Google Buzz designed to compete in the social network market. Youtube allows interactive comments related to 
video postings. Yahoo supports Yahoo Groups which has been a successful email based social networking application. Wikipedia, the only nondotcom, supports collaborative knowledge creation while Blogger focuses on individually led discussions.

In the aftermath of some recent natural disasters, social networks have been set up on Facebook and Twitter to facilitate communication among survivors. Large corporations have developed Facebook sites including Costco, Sony, Herbalife, Dell, Ford, CocaCola, Bain and Company, Avon, and Starbucks. A member of GE's consulting group comments on his organizations Facebook page that "managing change has become the 'silver bullet' in seeking the final component of successfully managing strategy" and that Facebook can be one useful tool for organizations that should "continuously embark on environmental scanning." [3]

A 2008 study of the motives for use of Facebook [4] concludes that keeping up with old friends is the primary motive, while meeting new friends falls relatively low on the list of motivations. A study on posting frequency for Facebook and Youtube related to the 2008 U.S. Presidential elections concludes: "The current loose coupling of YouTube and Face book is just the beginning of the evolution of egovernment and e-participation to more complex ... sociotechnical contexts." [5]

Another recent study of Faceook useage [6] among college students concludes that there is a positive improvement in social capital gained through social networks. Peng notes the important role of social capital and intense communications to the success of open-source innovation that has been improved through use of virtual collaboration tools[7]. Social capital can also be expected to be beneficial to collaborative data collection and issue management. However, a 1998 survey of over 19,000 visitors to the National Geographic website [8] concludes that internet use actually reduces social capital, perhaps because of unpleasant experiences while using the internet.

Social capital is, of course, somewhat difficult to measure. This study examines related measureable results including the frequency of postings on Facebook group sites and whether there is an increase in expected participation rates if social network applications are added to the mix of survey tools. As a collaborative tool, social networking sites have been examined by Totterdale who finds individuals using the new tools such as MySpace with usage influenced by age, gender, and geographic location [9].

Among the extensive research on survey participation, Wright and Schwager [10] show that online surveys can significantly reduce costs and increase participation rates with the use of a hyperlink to a survey being the preferred method for survey participation. Zhao and Luo [11] provide an online survey application and demonstrate how to use the Unified Process to develop this type of application.

Zhang [12] identifies problems related to internet based surveys, including: lack of equal access to the survey and internet that may create response bias, comfort with the internet survey format, effect of self selection for participation, multiple responses from the same respondent, technical expertise required for survey researchers. He concludes that internet surveys can't yet be used as "the only means to collect survey data if researchers need representative returns." He suggests that the most challenging aspect is the lack of research guidelines to address issues and concludes internet surveys have significant promise for future research efforts. Also agreeing that online surveys have significant advantages in terms of cost and speed, Evans and Mathur [13] identify the "perception as junk mail" for email or other online surveys as a potential weakness suggesting a brief introductory email with an op-in feature as a possible solution.

\section{Wildlife Management}

Environmental organizations make up many of the social management groups on Facebook. Collecting data and coordinating activities for wildlife and environmental management can be difficult and expensive. Wildlife often represents a public good that may be undervalued in business decision making. For example, development in the state of California has led some environmental groups to believe that deer populations will be endangered as their migratory corridors are impeded. In an effort to address this issue Congressman Ira Ruskin has proposed a data collection and mapping effort to identify corridors, but finding funding for this effort has been difficult and may prove to be insurmountable given the recent economic downturn.

Oil and gas development in Colorado with the potential destruction of deer corridors encouraged one old social network, the Southern Ute Indian Tribe, to collaborate with other groups to collect data 
and produce a map of deer corridors shared on the internet. [14].

The U.S. Bureau of Land Management (BLM) is involved in a making a number of decisions that might be improved with better data. For example, they are currently rounding up wild horses in the Western United States where they kept in stalls and may ultimately be destroyed. Although the goal of the BLM is to maintain healthy populations of wild horses, there is much disagreement about what that number should be and even the BLM admits that is has only very approximate estimates of the actual wild horse population. Numerous online social management networks have recently become active on Facebook to address this problem.

The following sections report an explorative study on the use of social networking applications for wildlife management and the potential of using surveys to collect data that can be used to inform management decisions.

\section{RESEARCH METHODOLOGY}

Facebook groups related to wildlife management were analyzed for information on how this application is being used to support social management networks. Of interest were some of the factors for success with success being defined as a high level of traffic as measured by the number of comments posted on the site. Also, a survey of college students was undertaken to analyze how social network applications could improve survey participation rates and to explore some general information on the students' use of social network applications.

A general statement of the research hypothesis directed at the Facebook group data is:

$\mathrm{H}_{1}$ : Frequency of postings on Facebook groups will be related to the number of group members.

Table 2 reports all of the hypotheses tested related to frequency of postings on Facebook groups. A variety of model specifications were tested to see which best explained the relationships between frequency of postings and the number of members in the group: linear, logarithmic, inverse, quadratic, and cubic. Two other potential success factors related to posting frequency on Facebook groups were if having a website associated with the group would increase postings $\left(\mathrm{H}_{1 \mathrm{E}}\right)$ and if different Facebook group types would be correlated with posting frequency $\left(\mathrm{H}_{1 \mathrm{~F}}\right)$. Facebook group types include: business, common interest, geography, organizations, sports and recreation, and student groups.

Table 2: Hypotheses Tested Using Data on Frequency of Postings for Facebook Groups Related to Wildlife Management

\begin{tabular}{|l|l|}
\hline $\mathrm{H}_{1 \mathrm{~A}}$ & $\begin{array}{l}\text { A linear model will explain the relation } \\
\text { between frequency of postings on a } \\
\text { Facebook group and the number of } \\
\text { members in the group }\end{array}$ \\
\hline $\mathrm{H}_{1 \mathrm{~B}}$ & $\begin{array}{l}\text { A logarithmic model will explain the } \\
\text { relationship. }\end{array}$ \\
\hline $\mathrm{H}_{1 \mathrm{C}}$ & $\begin{array}{l}\text { An inverse model will explain the } \\
\text { relationship }\end{array}$ \\
\hline $\mathrm{H}_{1 \mathrm{D}}$ & $\begin{array}{l}\text { A cubic model will explain the } \\
\text { relationship. }\end{array}$ \\
\hline $\mathrm{H}_{1 \mathrm{E}}$ & $\begin{array}{l}\text { Having a website associated with the } \\
\text { Facebook group will increase the } \\
\text { frequency of postings. }\end{array}$ \\
\hline $\mathrm{H}_{1 \mathrm{~F}}$ & $\begin{array}{l}\text { The type of Facebook group will be } \\
\text { correlated with the frequency of postings. } \\
\text { Groups types include: business, common } \\
\text { interest, geography, organizations, sports } \\
\text { and recreation, and student groups. }\end{array}$ \\
\hline
\end{tabular}

The survey of college students was used to test two general hypotheses. The first, $\mathrm{H}_{2}$, is posed to see how the use of online and social networking applications can be used to increase survey participation rates.

$\mathrm{H}_{2}$ : Use of online and social networking applications will increase participation rates for surveys.

Table 3: Hypotheses Tested Using Survey Data on Intent to Participate in a Survey

\begin{tabular}{|l|l|}
\hline $\mathrm{H}_{2 \mathrm{~A}}$ & $\begin{array}{l}\text { An online survey posted on an organization's } \\
\text { website will result in higher participation } \\
\text { rates than a paper survey mailed with a self } \\
\text { addressed stamped envelope for return }\end{array}$ \\
\hline $\mathrm{H}_{2 \mathrm{~B}}$ & $\begin{array}{l}\text { Adding Facebook support to an online survey } \\
\text { will increase participation rates }\end{array}$ \\
\hline $\mathrm{H}_{2 \mathrm{C}}$ & $\begin{array}{l}\text { Adding MySpace support to an online survey } \\
\text { will increase participation rates }\end{array}$ \\
\hline $\mathrm{H}_{2 \mathrm{D}}$ & $\begin{array}{l}\text { Adding Twitter support to an online survey } \\
\text { will increase participation rates }\end{array}$ \\
\hline $\mathrm{H}_{2 \mathrm{E}}$ & $\begin{array}{l}\text { An emailed survey with an internet link will } \\
\text { result in higher participation rates than a } \\
\text { paper survey mailed with a self addressed } \\
\text { stamped envelope for return }\end{array}$ \\
\hline
\end{tabular}


As Table 3 indicates, several social networking applications were investigated, including the use of emailed surveys, online surveys, online surveys supported by Facebook, MySpace, and Twitter.

A third general research hypothesis related to nonresponse bias attempts to see if there are categories of potential respondents who are more likely not to participate in a survey, creating sampling error in random sample surveys relying on voluntary responses .

$\mathrm{H}_{3}$ : Demographic factors will affect response rates for voluntary online surveys

Table 4: Hypotheses Related to Potential Nonresponse Bias for a Voluntary Survey

\begin{tabular}{|l|l|}
\hline $\mathrm{H}_{3 \mathrm{~A}}$ & $\begin{array}{l}\text { Participation rates will be related to the sex } \\
\text { of the respondent }\end{array}$ \\
\hline $\mathrm{H}_{3 \mathrm{~B}}$ & $\begin{array}{l}\text { Participation rates will be related to the age } \\
\text { of the respondent }\end{array}$ \\
\hline $\mathrm{H}_{3 \mathrm{C}}$ & $\begin{array}{l}\text { Participation rates will be related to the } \\
\text { number of organizations the respondent } \\
\text { belong to. }\end{array}$ \\
\hline $\mathrm{H}_{3 \mathrm{D}}$ & $\begin{array}{l}\text { Participation rates will be related to the } \\
\text { number of Facebook Friends the } \\
\text { respondent has. }\end{array}$ \\
\hline $\mathrm{H}_{3 \mathrm{E}}$ & $\begin{array}{l}\text { Participation rates will be related to the } \\
\text { number of hours the respondent spends on } \\
\text { the internet }\end{array}$ \\
\hline $\mathrm{H}_{3 \mathrm{~F}}$ & $\begin{array}{l}\text { Participation rates will be related to the } \\
\text { number of hours the respondent spends } \\
\text { studying for school. }\end{array}$ \\
\hline $\mathrm{H}_{3 \mathrm{G}}$ & $\begin{array}{l}\text { Participation rates will be related to the } \\
\text { number of hours the respondents spends } \\
\text { volunteering for organizations. }\end{array}$ \\
\hline
\end{tabular}

\section{Data Sources}

To obtain data from Facebook, a search was conducted during March, 2010, on the phrase "wildlife management". Of the 660 results, 103 were eliminated as not being related to the search phrase. Most of these cases just seemed to be unrelated groups; the search phrase was not apparent in most of the group descriptions. Basic data related to group membership, group type, and if the group maintained a related web site were collected from the remaining 557 groups.

A stratified sample was drawn from this group of 557 for more detailed investigation. The stratified sampled broke group membership down into categories of 100 member increments, i.e. 1 to 100 members, 101 to 200,201 to 300 , etc. The stratified sampling process ensured that the portion of each member category reflected the overall portion in the population. This was done because there are few groups with large memberships, but this procedure insures they are included in the sample to be investigated. For each of these groups, the number of postings and comments to the group wall were counted and the number of days that this information was available on Facebook was calculated. Some sites were relatively inactive and so had only a few postings over the past year or two. For other sites with more activity, the postings might be available only for the last month or two because the number of postings was large and wall size is limited.

The second source of data used in this study was a survey of 243 college students including undergraduate business majors, undergraduate information systems majors, and graduate business majors. Students were asked if they would respond to a survey for information from an organization with which they were familiar.

Survey options, as listed in Table 3, included: paper survey mailed to their address with a self addressed stamped envelope provided to return the survey; an online survey that could be filled out on the organizations website; an online survey supported by a Facebook group; an online survey with MySpace support; an online survey with Twitter support; or a survey that would be emailed containing a link that could be filled out online. Other general information concerning the type of social network applications used, number of organizations respondents belonged to, hours spent on various activities, number of Facebook friends, sex, age, method of accessing Facebook. These data were collected to test the hypothesis of Table 4 and to support some other exploratory data analysis reported in the next section.

\section{RESULTS}

\section{Facebook Group Postings and Comments}

Descriptive statistics for Facebook groups related to wildlife management are reported in Table 5 and a histogram of membership size for each group appears in Figure 1, a fairly common negative exponential shape.

The largest group in the sample by far, the WSPA (World Society for the Protection of Animals) had 213,447 group members near the beginning of March 2010 , and had increased to over 215,000 members by 
the end of March. The goal of this site is to "Fight Against Cruelty" [15]. Only 12 of the 557 Facebook groups examined had more than 2500 members. The median group size was 56. One group had no members; even the group administrator hadn't joined the group. By comparison, the median number of Facebook friends reported by students taking the survery who were using Facebook was 175.5. This first result, that individual Facebook users have more friends than groups have members is not surprising given the major use of Facebook is to keep in touch with friends. Facebook postings to an individuals wall (where comments are posted and communication most commonly occurs) can be announced via email while posting to a Facebook group are not announced. Users have to go to the group to see the posting, reducing somewhat the impact of posting to a group wall.

Table 5: Description Statistics for Number of Members in Facebook Groups Related to Wildlife Management $(\mathrm{N}=577)$

\begin{tabular}{|l|l|}
\hline Mean & 811.7 \\
\hline Median & 56 \\
\hline Mode & 3 \\
\hline Standard Deviation & 905.19 \\
\hline Kurtosis & 455.89 \\
\hline Skewness & 20.7 \\
\hline Maximum & 213,447 \\
\hline Minimum & 0 \\
\hline
\end{tabular}

The results of a linear regression model relating number of members in the group to the number of posting and comments per day on the group site appears in Table 6. As the p-Value indicates, the number of postings per day on group sites is significantly correlated with the number of members. Surprisingly, most small groups are not very active with about one post every three says as indicated by the constant term.

Postings increase with group size, but the incremental number of postings for each group member is very small as indicated by the significant but small coefficient on the number of members in the group. One conclusion here is that large groups in are not very interactive, perhaps because the group wall basically allows for one channel of communication. Discussion threads can be added, but are commonly not used.

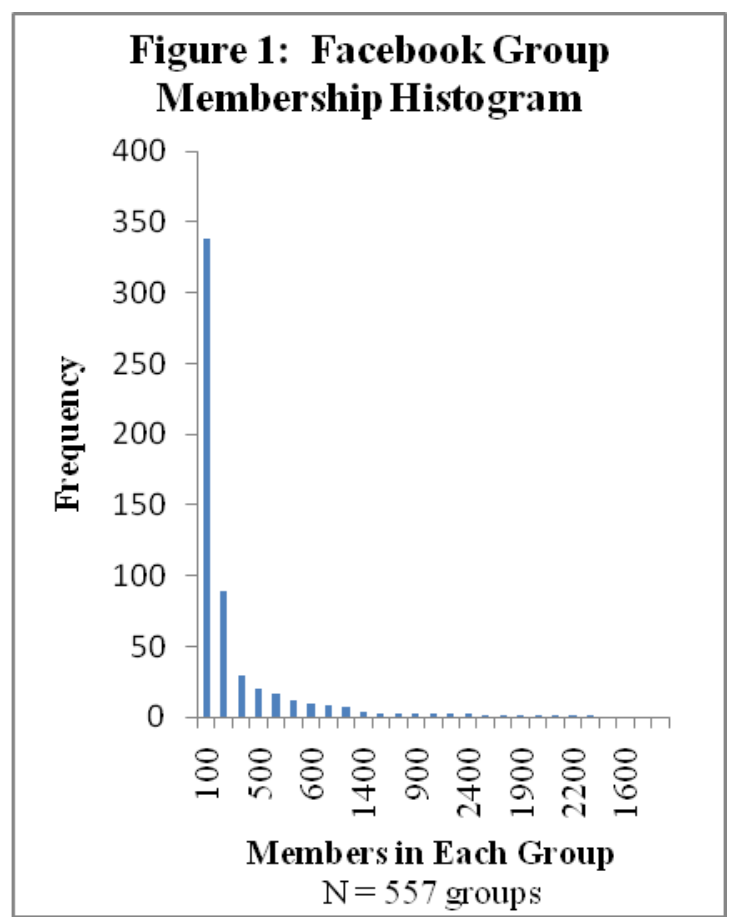

Table 6: Posting and Comments on the Facebook group site as Explained by the Number of Members in the Group

\begin{tabular}{|c|c|c|}
\hline \multicolumn{3}{|c|}{$\begin{array}{l}\text { Dependent Variable: Number of Postings and } \\
\text { Comments per day }\end{array}$} \\
\hline \multicolumn{3}{|l|}{ R Square $=.364$} \\
\hline Variable & Coefficient & $p$-Value \\
\hline Constant & 0.357 & $0.025^{*}$ \\
\hline $\begin{array}{l}\text { Number of } \\
\text { Members in Group }\end{array}$ & 0.00009448 & $0.000 *$ \\
\hline $\begin{array}{l}\mathrm{n}=178 \\
* \text { Statistically signi }\end{array}$ & at 05 level & etter \\
\hline
\end{tabular}

Results of alternative model specifications are reported in Table 7. The Quadratic model, as measured by the F-statistic, fits about as well as the linear model. The Cubic model provides the next best fit, followed by the logarithmic, all significant. The inverse model proves to be a bad choice.

\begin{tabular}{|c|c|c|}
\hline \multicolumn{3}{|c|}{$\begin{array}{c}\text { Table 7: Alternative Models Relating Facebook } \\
\text { Group Postings and Comments to Number of } \\
\text { Members }\end{array}$} \\
\hline Model Type & $F$-statistic & Significance \\
\hline Linear & 100.598 & 0.000 \\
\hline Logarithmic & 33.842 & 0.000 \\
\hline Inverse & 0.687 & 0.408 \\
\hline Quadratic & 99.498 & 0.000 \\
\hline Cubic & 78.433 & 0.000 \\
\hline $\mathrm{n}=178$ & & \\
\hline
\end{tabular}


Since larger groups make it very difficult to have interactive communications on Facebook, the 12 groups with total membership of over 2500 were removed from the same and the data was analyzed again. As reported in Table 8, the number of incremental posts per member goes up significantly for smaller groups, but it is still very low at about 1 posting every 1000 days for each member of the group. The constant term is not significantly different from zero. If there are no members there would be no comments posted, a logical result for the model.

Table 8: Posting and Comments on the Facebook group site as Explained by the Number of Members in the Group (groups less than 2500 members)

\begin{tabular}{|c|c|c|}
\hline \multicolumn{3}{|c|}{$\begin{array}{l}\text { Dependent Variable: Number of Postings and } \\
\text { Comments per day }\end{array}$} \\
\hline \multicolumn{3}{|l|}{ R Square $=.301$} \\
\hline Variable & Coefficient & $p$-Value \\
\hline Constant & 0.096 & 0.352 \\
\hline $\begin{array}{l}\text { Number of } \\
\text { Members in Group }\end{array}$ & 0.001 & $0.000 *$ \\
\hline $\begin{array}{l}\mathrm{n}=166 \\
* \text { Statistically signi }\end{array}$ & مeve & etter \\
\hline
\end{tabular}

As reported in Table 9, the linear model best explains the relationship between daily postings and membership size. Again, however, all of the models but the inverse are significant.

\begin{tabular}{|c|c|c|}
\hline \multicolumn{3}{|c|}{$\begin{array}{c}\text { Table 9: Alternative Models Relating Facebook } \\
\text { Group Postings and Comments to Number of } \\
\text { Members (groups less than 2500) }\end{array}$} \\
\hline Model Type & $F$ - statistic & Significance \\
\hline Linear & 16.41 & 0.000 \\
\hline Logarithmic & 9.96 & 0.002 \\
\hline Inverse & 0.749 & 0.388 \\
\hline Quadratic & 8.24 & 0.000 \\
\hline Cubic & 6.68 & 0.000 \\
\hline \multicolumn{3}{|l|}{$n=166$} \\
\hline
\end{tabular}

As reported in Table 10, presence of a website associated with the Facebook group did not significantly increase the frequency of postings. The p-Value of 0.15 is not too much above the default 0.05 , but the coefficient is negative, suggesting the counterintuitive result that presence of a website discourages postings on the Facebook site. Perhaps there is a tendency for some members of groups with both Facebook and websites to relay on the website for information and not post as much on the Facebook group. Frequency of postings was not correlated with any type of group. Hypothesis $\mathrm{H}_{1 \mathrm{E}}$ and $\mathrm{H}_{1 \mathrm{~F}}$ are not accepted.

Table 10: Posting and Comments on the Facebook group site as Explained by the Number of Members, Presence of Supporting Website, and Group Type

\begin{tabular}{|c|c|c|}
\hline \multicolumn{3}{|c|}{$\begin{array}{l}\text { Dependent Variable: Number of Postings and } \\
\text { Comments per day }\end{array}$} \\
\hline Variable & Coefficient & $p$-Value \\
\hline Constant & 0.757 & 0.197 \\
\hline $\begin{array}{l}\text { Number of } \\
\text { Members in Group }\end{array}$ & 0.00009554 & $0.000 *$ \\
\hline Website $(1=$ yes $)$ & -0.488 & 0.151 \\
\hline Business Group & 0.129 & 0.872 \\
\hline $\begin{array}{l}\text { Common Interest } \\
\text { Group }\end{array}$ & 0.031 & 0.960 \\
\hline Geography Group & 0.036 & 0.979 \\
\hline Organizations & -0.151 & 0.797 \\
\hline $\begin{array}{l}\text { Sports and } \\
\text { Recreation }\end{array}$ & -0.426 & 0.611 \\
\hline Student Group & -0.554 & 0.456 \\
\hline
\end{tabular}

\section{Results from the Survey of Business Students}

Descriptive statistics for the survey conducted of business students is reported in Table 11. About 86 percent use Facebook and of those the median number of Facebook friends is 175.5, as mentioned, significantly higher than the median number of members in Facebook groups.

Table 11: Descriptive Statistics from Survey of Business Students $(n=243)$

\begin{tabular}{|l|l|}
\hline Average Age & 25.4 \\
\hline Mininum Age & 18.0 \\
\hline Maximum Age & 53.0 \\
\hline Number of Hours per Week on Internet & 34.2 \\
\hline Number of Hours per Week Studying & 15.1 \\
\hline Number of Hours per week Volunteering & 0.83 \\
\hline Percent Using Facebook & $86.4 \%$ \\
\hline $\begin{array}{l}\text { Average Number of Friends If Using } \\
\text { Facebook }\end{array}$ & 207.16 \\
\hline $\begin{array}{l}\text { Median Number of Friends If Using } \\
\text { Facebook }\end{array}$ & 175.5 \\
\hline $\begin{array}{l}\text { Percent of Time Accessing Social Media } \\
\text { on a Laptop }\end{array}$ & $65.5 \%$ \\
\hline Percent of Time Using a Desktop & $18.5 \%$ \\
\hline Percent of Time Using a Mobil Device & $15.1 \%$ \\
\hline
\end{tabular}


Table 12 reports frequency of use for various social media. Students were asked how often they used each of the following social media applications (App in the table): never, occasionally ("some" in the table), monthly, weekly, or daily. Although Care2 is an application specifically designed to help public organizations, 98.7 percent of those surveyed never used it. Youtube scored the highest number of users with 92.2 percent using it at least sometimes. Most of the action is on Facebook, however, with 56.8 percent of the students reporting daily usage. This is consistent with the traffic data reported in Table 1. MySpace seems to be falling behind with this group.

Table 12: Frequency of Use for Social Media Applications by Students in Survey

\begin{tabular}{|l|l|l|l|l|l|}
\hline & \multicolumn{6}{|c|}{ Percentage Frequency of Use } \\
\hline App & Never & Some & Month & Week & Day \\
\hline Twitter & 76.5 & 12.3 & 2.1 & 3.3 & 5.8 \\
\hline Facebook & 13.6 & 11.1 & 4.1 & 14.4 & 56.8 \\
\hline MySpace & 67.1 & 24.3 & 3.7 & 3.3 & 1.2 \\
\hline Linkedin & 60.5 & 13.6 & 10.7 & 11.5 & 3.1 \\
\hline Youtube & 7.8 & 19.3 & 9.9 & 32.9 & 30.0 \\
\hline Flickr & 74.1 & 17.7 & 4.5 & 2.1 & 1.6 \\
\hline Bebo & 97.9 & 1.6 & 0.4 & 0 & 0 \\
\hline Friendster & 94.2 & 5.3 & 0.4 & 0 & 0 \\
\hline Orket & 95.5 & 1.2 & 1.6 & 0.8 & 0.8 \\
\hline Xanga & 94.2 & 4.5 & 0 & 0.4 & 0.8 \\
\hline Care2 & 98.7 & 0.8 & 0.4 & 0 & 0 \\
\hline & & & & & \\
\hline
\end{tabular}

Table 13 summarizes the expected participation rates for each of the survey types investigated. Clearly all of the methods using the internet were preferred by the respondents. The best result was $92 \%$ for an online survey with Facebook support, indicated on the table as "Online + Facebook". The last three categories in this table indicate that the survey is available at a link on the organization's website and that support is provided by the organizations Facebook group. Support, in this case, would include answering questions about the use of the survey, how to complete the survey, and postings among members of the group involved in the survey. It is hypothesized that the interactivity provided by social networking applications increases social capital, leading to higher participation rates.
Table 13: Survey Participation Rates by Survey Type

\begin{tabular}{|l|l|}
\hline Survey Method & Participation Rates \\
\hline Mailed, Paper Survey & $35 \%$ \\
\hline Emailed Survey & $61 \%$ \\
\hline Online Survey & $86 \%$ \\
\hline Online + Facebook & $92 \%$ \\
\hline Online + MySpace & $88 \%$ \\
\hline Online + Twitter & $88 \%$ \\
\hline
\end{tabular}

Table 14 addresses the hypothesis tested in terms of increased participation rates for survey collection when a social networking application is used to support an online survey. A paired samples test was conducted for the difference in the mean participation rate. As reported in the table, the increment for using Facebook is significant, but not as large as might be expected, only about a 5.3 percentage point increase. Improvements from MySpace and Twitter were marginal but significant at the 90 percent level. MySpace and Twitter support would add only about 1.2 percentage points to the participation rate for an online survey.

Table 14: Test of Difference In Survey Participation Rates Compared to a Mailed, Paper Survey

\begin{tabular}{|c|c|c|c|}
\hline $\begin{array}{l}\text { Survey } \\
\text { Type: }\end{array}$ & $\begin{array}{l}\text { Difference in } \\
\text { Participation } \\
\text { Rate }\end{array}$ & t-stat & Sig. \\
\hline \multicolumn{4}{|l|}{ OnLine } \\
\hline + Facebook & +0.053 & 3.698 & $0.000 * *$ \\
\hline + MySpace & +0.012 & 1.739 & $0.083^{*}$ \\
\hline + Twitter & +0.012 & 1.739 & $0.083^{*}$ \\
\hline \multicolumn{4}{|c|}{$\begin{array}{l}\text { A + sign above indicates the application is used to } \\
\text { support an online survey hosted on the organization's } \\
\text { website, not that the survey is delivered only by the } \\
\text { application. } \\
* \text { Significant at better than } 0.10 \text { level } \\
* * \text { Significant at better than } 0.05 \text { level }\end{array}$} \\
\hline
\end{tabular}

To test the third set of hypotheses related to nonresponse bias, data on the following variables were collected in the survey of business students: male or female respondent, age of respondent, number of organizations the respondent belonged to, number of hours spent by the respondent on the internet, number of Facebook friends.

As reported in Table 15, a binary logit model for online survey participation (yes or no variable) against explanatory variables collected in the student 
survey data revealed no strongly significant relationships, although one results is just above the 0.05 level for the $\mathrm{p}$-Valaue. Males were somewhat less likely to respond ( $\mathrm{p}$-Value 0.286) older respondents were also somewhat less likely to respond $(\mathrm{p}$-Value $=0.250)$, and students who spent more time studying were somewhat less likely to respond $(\mathrm{p}-$ Value $=0.194)$. This lack of significance is surprising, but promising. It suggests no significant bias from survey non-response, an issue of significant speculation in the literature. Happily, H3 is rejected with no strong evidence of non-response bias.

The strongest significance reported in the table is counterintuitive. There appears to be a negative relationship between the number of hours spent volunteering and willingness to participate in an online survey ( $\mathrm{p}$-Value of 0.052). Perhaps, as suggested by one researcher quoted in the introduction, they have had some negative experience with online activities that has actually reduced their social capital with organizations using online tools.

Table 15: Willingness to Participate in an Online Survey (yes or no) as Explained by Some Demographic Variables

\begin{tabular}{|c|c|c|}
\hline \multicolumn{3}{|c|}{$\begin{array}{l}\text { Dependent Variable: Willingness to Participate in } \\
\text { an Online Survey (Yes or No) }\end{array}$} \\
\hline \multicolumn{3}{|l|}{ Binary Logistic Model } \\
\hline Variable & Coefficient & $p$-Value \\
\hline Constant & 5.302 & $0.003 *$ \\
\hline Male $=1$, Female $=0$ & -0.665 & 0.286 \\
\hline Age & -0.059 & 0.250 \\
\hline Org Membership & .054 & 0.592 \\
\hline Facebook Friends & 0.000 & 0.577 \\
\hline Hours Week on Internet & -0.004 & 0.753 \\
\hline Hours Studying & -0.026 & 0.194 \\
\hline Hours Volunteering & -0.189 & $0.052 * *$ \\
\hline \multicolumn{3}{|c|}{$\begin{array}{l}\mathrm{n}=188 \\
* \text { Statistically significant at } .05 \text { level or better } \\
* * \text { significant at } .10 \text { level }\end{array}$} \\
\hline
\end{tabular}

As a general data exploration, a number of other variables collected from the survey were correlated. The most significant result was that older respondents tended to have fewer friends on Facebook. Men were somewhat likely to have fewer friends than women.

\section{CONCLUSIONS}

With regard to the first set of hypotheses exploring the frequency of Facebook postings, for groups with less than 2,500 members, a linear model best explains the relationship between the posting frequency and group size, supporting hypothesis $\mathrm{H}_{1 \mathrm{~A}}$. Nonlinear effects seem to appear for large groups so that a quadratic model works as well as a linear model over all group sizes. Postings per member decline for very large groups. Facebook is not designed to handle large group interactions, so this is not a surprising result.

As measured by the R-square, about 30 to 36 percent of the variation in posting frequency is explained by group size. A lot of other factors obviously come into play and may be the basis for future research.

The second set of hypotheses was concerned with survey partition rates. Expected participation in online surveys is significantly higher than for mailed surveys $\left(\mathrm{H}_{2 \mathrm{~A}}\right)$. This effect, combined with cost savings, certainly contributes to the popularity of online surveys and the wide range of internet based survey applications that have been recently developed.

Although offering Facebook support to an online survey significantly increases expected participation rates $\left(\mathrm{H}_{2 \mathrm{~B}}\right)$, the increase is not dramatic, about a 5 percentage point gain. MySpace and Twitter support $\left(\mathrm{H}_{2 \mathrm{C}}\right.$ and $\left.\mathrm{H}_{2 \mathrm{D}}\right)$ resulted in an even smaller estimated gain of about one percentage point and the hypotheses were supported with p-Values of only about 10 percent.

The data indicate that emailed surveys will get higher participation rates than paper surveys distributed through the regular mail $\left(\mathrm{H}_{2 \mathrm{E}}\right)$, but the rate is significantly lower than for online surveys. Comments from respondents indicated that there have been so many scams related to email that many were reluctant to click on links contained in email even if from an apparently benign source.

The third set of hypotheses examined how demographics related to participation rates. None of the hypotheses were supported at or below the 0.05 level of significance, although one counterintuitive result was very close with hours spent volunteering negatively correlated with survey participation. The lack of correlation between participation and most of the demographic variables is an encouraging result since it suggests that there may not be significant non-response bias in voluntary surveys. Among the 
variables tested were the respondents' age, sex, memberships in organization, Facebook friends, hours spent per week on the internet, hours spent studying, and hours spent volunteering.

As general conclusion, it seems that Facebook groups have some marginal advantage in collecting structured information from online surveys. Perhaps the more important contribution from Facebook, given the current state of software, is the unstructured information. Examples are posting of events or issues on large groups where many interested individuals may see the information.

The internet has provided some useful tools aiding the development of social management networks such as websites for making information available conveniently and at a low cost; also, email that can reach large groups for little cost,. While most of the Facebook groups examined in this study were not very successful for social management, a few demonstrate the potential of this new media application.

As a qualitative result from examining the Facebook groups, it seems that internet users are increasingly banding together using social networking applications with management objectives in general and for wildlife management in particular. One successful organization discovered during the data collection process was Quality Deer Management. With a variety of regional Facebook sites created by members of the organization, their website aggregates data from volunteers into a detailed online map of density for white-tail deer.

Future research into this topic might usefully focus on the success factors for social management networks and implementation issues for gathering structured data from surveys. Data mining of the unstructured information available in comments made to social networking applications could become a valuable tool for environmental scanning.

\section{REFERENCES}

1. Inkpen, Andrew C., and Tsang, Eric W.K. (2005). Social Capital, Networks, and Knowledge Transfer. Academy of Management Review. 30(1). 146-165.

2. Wasko, Molly McLure, Faraj, Samer (2005). Why Should I Share? Examining Social Capital and Knowledge Contribution in Electronic Networks of Pactice. MIS Quarterly. (29)1. 35-58.
3. Victor, Fred (2009). GE Consult: Strategic Management - An Ongoing Process. Available at: http://www.facebook.com/note.php? note_id=210160881835

4. Joinson, Adam N. (2008). Looking at, looking up, or keeping up with people?: motives and use of facebook. Proceedings of the twenty-sixth annual SIGCHI Conference on Human Factors in Computing. Pp. $1027-1036$.

5. Robertson, Scott. P., Vatrapu, Ravi K., Medina, Richard (2010). Online Video "Friends"Social Networking: Overlapping Online Public Spheres in the 2008 U.S. Presidential Election. Paper under submission, but available at: http://www.itu.dk/people/rkva/EB22/readings/Robert sonEtAl_JITP Revision2009_09 14.pdf

6. Ellison, N. B., Steinfield, C., \& Lampe, C. (2007). The benefits of Facebook "friends:" Social capital and college students' use of online social network sites. Journal of Computer-Mediated Communication, 12(4), article 1. http://jcmc.indiana.edu/vol12/issue4/ellison.html

7. Peng, Gang (2009). "Critical success factors for opensource innovation: the case of open source software development. Issues in Information System. X(2) 157-164

8. Wellman, Barry, Haase; Anabel Quan; White, James; Hampton, Keith (2001). "Does the internet increase, decrease, or supplement social capital?" American Behaviorial Scientist. 45(3) 436-455.

9. Totterdale, Robert L., (2009). Globalization, Collaboration, and Social Networking. Issues in Information Systmes, 10(2). 249-256.

10. Wright, Beverly, and Schwager, Paul H. (2008). Online Survey Research: Can Response Factors Be Improved. Journal of Internet Commerce 7(2). 253269

11. Zhao, Haifeng, and Luo, Yuan. (2005). Using Unified Process to Develop an Online Survey Application. Proceedings of the IADIS International Conference on the World Wide Web and the Internet. 159-164

12. Zhang, Yin (1999). Using the Internet for Survey Research: A Case Study. Journal of the American Society for Information Science 5(1). 57-68 
13. Evans, Joel R., and Mathur, Anil (2005). The value of online surveys. Internet Research 15(2). 195-219.

14. HD Mountains Mule Deer Corridor, Map created by Aran Johnson, Division of Wildlife Resource Management, Southern Ute Indian Tribe, available at:

http://www.coloradowild.org/HDMuleDeer_FTRWe b-1.pdf

15. Facebook group WSPA (world Society for pretection of animals). Avalable at: http://www.facebook.com/group.php?gid=862781498 $2 \&$ ref=search\&sid=692948269.2839690731..1 